\title{
PENGARUH MANAJEMEN LABA TERHADAP \\ PERENCANAAN BIAYA MODAL EKUITAS DENGAN \\ RETURN ON ASSETS (ROA) SEBAGAI VARIABEL MODERATING PADA PERUSAHAAN MANUFAKTUR YANG TERDAFTAR DI BEI
}

\author{
Zul Hendri, Desi Nurhazana \\ Sekolah Tinggi Ilmu Ekonomi (STIE) Syariah Bengkalis \\ Email: hendricks.stiesbks@gmail.com,desi.nurhazana19@gmail.com
}

\begin{abstract}
ABSTRAK
Penelitian ini bertujuan untuk mengetahui apakah manajemen laba berpengaruh terhadap perencanaan biaya modal ekuitas pada Perusahaan Manufaktur periode 2013-2017 dan untuk mengetahui apakah Return On Assets (ROA) mampu memoderasi hubungan antara manajemen laba terhadap biaya modal ekuitas pada Perusahaan Manufaktur periode 2013-2017. Penelitian ini baru pertama dilakukan karena menggunakan pendekatan kuantitatif dengan menggunakan data laporan keuangan yang terdaftar di Bursa Efek Indonesia sebagai data sekunder. Pengolahan data menggunakan program SMART PLS Versi 3.0. Data laporan keuangan yang digunakan adalah laporan keuangan perusahaan manufaktur dari tahun 2013-2017. Teknik sampel yang digunakan adalah purposive sampling sehingg sampel yang digunakan sebanyak 18 perusahaan. Hasil penelitian menunjukkan bahwa manajemen laba berpengaruh terhadap perencaanaan biaya modal ekuitas dan Return On Assets (ROA) tidak mampu untuk memoderasi hubungan antara manajemen laba terhadap perencanaan biaya modal ekuitas.
\end{abstract}

Kata Kunci: Manajemen Laba, Biaya Modal Ekuitas, ROA, Moderating, BEI.

\section{PENDAHULUAN}

Seiring dengan kemajuan perekonomian, pasar modal berkembang menjadi salah satu alternatif sumber pembiayaan strategis yang dipilih oleh para pelaku bisnis. Pasar modal dan industri sekuritas merupakan salah satu indikator untuk menilai perekonomian suatu negara berjalan dengan baik atau tidak. Hal ini disebabkan perusahaan yang masuk kepasar modal adalah perusahaan-perusahaan besar dan kredibel di negara yang bersangkutan, sehingga bila terjadi penurunan kinerja pasar modal dikatakan telah terjadi pula penurunan kinerja di sektor riil. Dan kondisi tersebut merupakan sinyal telah terjadinya penurunan perekonominan suatu negara.

Pengertian pasar modal menurut Keputusan Menteri Keuangan RI No. 1548/KMK/1990 tentang peraturan pasar modal adalah suatu sistem keuangan yang terorganisasi, termasuk didalamnya adalah bank-bank komersial dan sebuah lembaga perantara dibidang keuangan, serta keseluruhan surat-surat berharga yang beredar. Sedangkan dalam arti sempit pasar modal adalah suatu tempat dalam pengertian fisik yang mengorganisasikan transaksi penjualan efek atau disebut sebagai bursa efek. Pengertian bursa efek atau stock exchange adalah suatu sistem 
yang teroganisir yang mempertemukan antara penjual dan pembeli efek yang dilakukan baik secara langsung maupun melalui wakil-wakilnya. Bursa efek ini berfungsi untuk menjaga kontinuitas pasar dan menciptakan harga efek yang wajar melalui mekanisme permintaan dan penawaran. (Sutrisno 2001, 341)

Pilihan investasi di sektor konsumsi bisa menjadi alternatif isi portofolio ketika investasi di perusahaan sektor lain masih menunjukkan pelemahan kinerja. Misalnya, ketika sektor properti mengalami penurunan kinerja cukup signifikan sejak BI rate dinaikkan. Juga disaat harga komoditas tambang dan perkebunan belum menunjukan kenaikan harga, sehingga emiten-emiten perkebunan dan pertambangan masih akan menurun kinerjanya. Meredupnya kinerja perusahaan di sektor lain mendorong investor mulai mencari alternatif investasi pada sektor yang masih bisa tumbuh. Salah satunya adalah sektor konsumsi. Beberapa tahun sebelumnya, perusahaan-perusahaan sektor konsumsi Indonesia dikenal tahan terhadap krisis yang sempat terjadi. Pada saat krisis, kinerja dan pergerakan sahamnya memang ikut turun, tapi tidak begitu signifikan. Setelah itu, kinerja perusahaan consumer goods ini bisa dapat pulih dengan begitu cepatnya. Sehingga, di masa harga komoditas perkebunan dan pertambangan belum membaik, investor pun mulai memperhitungkan consumer goods sebagai alternatif investasinya. Adapun kinerja emiten sektor konsumsi di kuartal dua tahun 2014 yaitu sebagai berikut:

Tabel 1

Data Net Income Beberapa Emiten Sektor Konsumsi

\begin{tabular}{|l|r|r|c|}
\hline \multicolumn{5}{|c|}{ PERFORMANCE OF NET INCOME } \\
\hline CODE & \multicolumn{1}{|c|}{2013} & \multicolumn{1}{c|}{2014} & Growth $(\%)$ \\
\hline DLTA & 130.195 .428 .000 & 139.999 .600 .000 & $8 \%$ \\
\hline INDF & 2.067 .727 .000 .000 & 2.985 .399 .000 .000 & $44 \%$ \\
\hline MYOR & 460.055 .255 .700 & 308.958 .463 .806 & $-33 \%$ \\
\hline ROTI & 75.724 .027 .500 & 100.296 .258 .989 & $32 \%$ \\
\hline SKBM & 10.072 .276 .943 & 20.096 .360 .374 & $100 \%$ \\
\hline ULTJ & 219.989 .685 .819 & 123.771 .256 .910 & $-44 \%$ \\
\hline GGRM & 2.231 .732 .000 .000 & 2.734 .946 .000 .000 & $23 \%$ \\
\hline HMSP & 5.008 .682 .000 .000 & 5.031 .265 .000 .000 & $0 \%$ \\
\hline WIIM & 79.239 .141 .325 & 53.452 .775 .678 & $-33 \%$ \\
\hline DVLA & 78.643 .743 .000 & 50.238 .208 .000 & $-36 \%$ \\
\hline KAEF & 43.172 .509 .640 & 71.540 .541 .007 & $66 \%$ \\
\hline KLBF & 948.042 .228 .485 & 1.019 .093 .783 .870 & $7 \%$ \\
\hline MERK & 118.966 .514 .000 & 101.750 .405 .000 & $-14 \%$ \\
\hline TSPC & 434.104 .722 .264 & 417.505 .477 .406 & $-4 \%$ \\
\hline ADES & 31.989 .000 .000 & 20.877 .000 .000 & $-35 \%$ \\
\hline TCID & 78.070 .399 .289 & 94.418 .440 .454 & $21 \%$ \\
\hline UNVR & 2.823 .890 .000 .000 & 2.847 .991 .000 .000 & $1 \%$ \\
\hline Subr: & & & \\
\hline
\end{tabular}

Sumber: www.seputarforex.com 
Dari tabel diatas dapat dijelaskan bahwa besarnya beban operasional perusahaan menyebabkan dari berbagai emiten mengalami pencatatan laba bersih yang turun signifikan. Meskipun, ada beberapa perusahaan mencatatkan pertumbuhan laba negatif, namun ada juga beberapa perusahaan yang masih mencatat pertumbuhan laba bersih positif dan stagnan. (Aziz 2014)

Sinergi pemerintah Indonesia terus mendorong para investor untuk menanamkan modal di sektor manufaktur tanah air. Sektor manufaktur merupakan salah satu sektor yang diandalkan menjadi perekonomian nasional. Maka dari itu mereka mengajak para investor untuk terus meningkatkan investasinya terutama diindustri manufaktur. Untuk membandingkan peran manufaktur dengan beberapa sektor lain seperti pertanian dan perdagangan yang memberikan kontribusi dibawah 13,2\%. Bahkan, beberapa sektor lainnya seperti jasa keuangan, pendidikan dan kesehatan masih dibawah 4,2\%. Pertumbuhan industri pengolahan triwulan II 2017 mencapai 2,4\% dan triwulan IV 5,14\%. Kondisi ini merupakan momentum pertumbuhan yang baik untuk diteruskan dan dijaga kesinambungannya dengan menciptakan iklim investasi dan kepastian berusaha bagi para investor. Dalam Survei Kegiatan Dunia Usaha (SKDU) kuartal III 2016 terjadi perlambatan industri manufaktur khususnya industri makanan dan minuman hal ini menjadi pendorong utama pelemahan dunia usaha yang juga terindikasi oleh penurunan kapasitas produksi, penurunan volume produksi serta kontraksi penggunaan tenaga kerja. (Anggraeni 2019)

Keputusan untuk menginvestasikan saham bukan merupakan hal yang mudah. Ada banyak pertimbangan dan analisis yang perlu diperhatikan agar tidak menimbulkan kerugian dimasa depan. Maka dari itu salah satu bentuk informasi yang dibutuhkan oleh para pengambil keputusan, terutama bagi investor dan kreditor adalah laporan keuangan. Agar informasi keuangan bisa membuat para investor dan kreditor tertarik untuk melakukan investasi diperusahaan itu, kadangkala manajer perusahaan melakukan beberapa tindakan agar laporan keuangan perusahaan tampak bagus. Maka dari itu manajemen berusaha mengatur laba agar kinerja perusahaan terlihat bagus.

Manajemen laba merupakan pengungkapan manajemen sebagai alat intervensi langsung manajemen dalam proses pelaporan keuangan melalui pengolahan pendapatan atau keuntungan dengan maksud untuk mendapatkan keuntungan atau manfaat tertentu baik bagi manajer maupun perusahaan yang dilandasi oleh faktor-faktor ekonomi. Manajemen laba ialah upaya campur tangan dalam proses pelaporan keuangan eksternal dengan memiliki tujuan untuk menguntungkan diri sendiri (Purnomo 2009). Manajemen laba ini ialah salah satu faktor yang dapat mengurangi kredibilitas laporan keuangan, manajemen laba menambahkan bias dalam laporan keuangan dan dapat mengganggu pemakaian laporan keuangan yang mempercayai angka hasil laba rekayasa tersebut sebagai angka laba tanpa rekayasa. Sebagaimana pengertian yang dijelaskan bermaksud manajemen laba menyebabkan banyak informasi yang harus diungkap oleh perusahaan, sehingga berkonsekuensi terhadap meningkatnya biaya yang dikeluarkan oleh perusahaan untuk menyediakan informasi bagi publik. Manajemen laba meningkat seiring dengan meningkatnya biaya modal ekuitas (cost of equity capital) yang dikeluarkan perusahaan.

Selain itu Return On Assets (ROA) juga diperlukan dalam manajemen laba dan mempengaruhi investor dalam menentukan tingkat pengembalian atas 
investasi yang dilakukan karena ROA merupakan ketersediaan informasi. Semakin besar ROA menunjukkan kinerja yang semakin baik karena tingkat pengembalian yang semakin besar. Dari hal ini dapat menarik investor untuk menanamkan modalnya pada perusahaan. Didalam perusahaan besar return yang diharapkan akan diterima dimasa yang akan datang lebih besar dibandingkan perusahaan kecil. Selain investor, kreditur juga lebih percaya untuk meminjamkan modalnya kepada perusahaan besar karena risiko atas kegagalan kredit akan semakin kecil.

\section{Gambar 1}

Kerangka Pemikiran

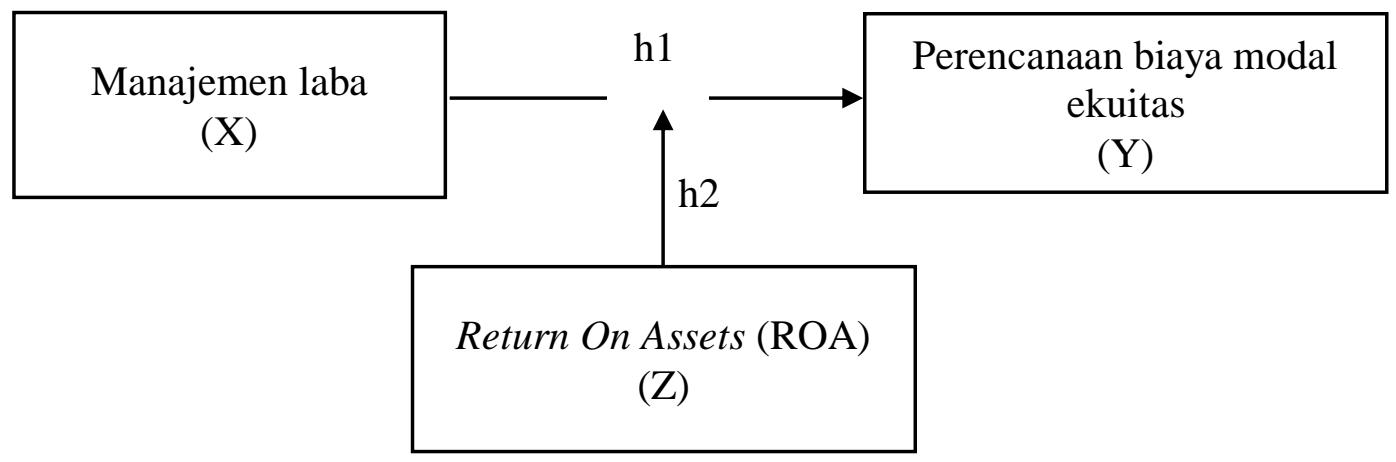

Tabel 2

Definisi Variabel

\begin{tabular}{|c|c|c|c|}
\hline Variabel & Pengertian & Indikator & Jenis Skala \\
\hline $\begin{array}{l}\text { Manajemen } \\
\text { laba } \\
(\mathrm{X})\end{array}$ & $\begin{array}{l}\text { Pemilihan kebijakan } \\
\text { akuntansi oleh manajer } \\
\text { dari standar akuntansi } \\
\text { yang ada dan secara } \\
\text { alamiah dapat } \\
\text { memaksimumkan nilai } \\
\text { pasar perusahaan (Jumirin } \\
\text { 2011). }\end{array}$ & $\mathrm{ML}=\frac{\text { Akrual modal kerja }(\mathrm{t})}{\text { Penjualan periode }(\mathrm{t})}$ & Rasio \\
\hline $\begin{array}{l}\text { Biaya modal } \\
\text { ekuitas } \\
(\mathrm{Y})\end{array}$ & $\begin{array}{l}\text { Tingkat pengembalian } \\
\text { yang diinginkan oleh } \\
\text { penyedia dana baik } \\
\text { investor maupun kreditor } \\
\text { (Ifonie 2012). }\end{array}$ & $r=\frac{\left(\mathrm{Bt}+\mathrm{X}_{\mathrm{t}+1}-\mathrm{Pt}\right)}{\mathrm{Pt}}$ & Rasio \\
\hline $\begin{array}{l}\text { Return On } \\
\text { Assets (ROA) } \\
(\mathrm{Z})\end{array}$ & $\begin{array}{l}\text { Pengukuran kemampuan } \\
\text { perusahaan secara } \\
\text { keseluruhan didalam } \\
\text { menghasilkan keuntungan } \\
\text { dengan jumlah } \\
\text { keseluruhan aktiva yang } \\
\text { tersedia didalam } \\
\text { perusahaan (Watung } \\
\text { 2016). }\end{array}$ & ROA $=\frac{\text { Laba bersih setelah pajak }}{\text { Total aktiva }}$ & Rasio \\
\hline
\end{tabular}




\section{TINJAUAN PUSTAKA}

\section{Manajemen Laba}

Menurut Assih Dan Gudono manajemen laba ialah suatu proses yang dilakukan dengan sengaja dalam batasan General Addopted Accounting Principles (GAAP) untuk mengarah pada tingkatan laba yang dilaporkan. Sedangkan menurut Fischer Dan Rozenzwig, manajemen laba ialah tindakan manajer yang menaikkan (menurunkan) laba yang dilaporkan dari unit yang menjadi tanggung jawabnya yang tidak mempunyai hubungan dengan kenaikan atau penurunan profitabilitas perusahaan dalam jangka panjang.

Dapat disimpulkan bahwa secara umum manajemen laba didefinisikan sebagai upaya manajer perusahaan untuk mengintervensi atau memengaruhi informasi dalam laporan keuangan dengan tujuan untuk mengelabui stakeholder yang ingin mengetahui kinerja dan kondisi perusahaan.

Manajemen laba diproksi berdasarkan rasio akrual modal kerja dengan penjualan, yaitu sebagai berikut:

Manajemen laba $(\mathrm{ML})=$ Akrual modal kerja $(\mathrm{t}) /$ Penjualan periode $(\mathrm{t})$

Akrual modal kerja $=\Delta \mathrm{AL}-\Delta \mathrm{HL}-\Delta \mathrm{Kas}$

Keterangan :

$\Delta \mathrm{AL}=$ perubahan aktiva lancar pada periode $\mathrm{t}$

$\Delta \mathrm{HL}=$ perubahan hutang lancar pada periode $\mathrm{t}$

$\Delta$ Kas $=$ perubahan kas dan ekuivalen pada kas pada periode $\mathrm{t}$

\section{Biaya Modal Ekuitas}

Biaya modal yang dimaksudkan adalah biaya modal yang bersifat eksplisit, yaitu sama dengan tingkat diskonto yang dapat menjadikan nilai sekarang (present value) dana neto yang diterima perusahaan sama dengan nilai sekarang semua dana yang harus dibayarkan karena penggunaan dana tersebut beserta pelunasannya. Dana yang harus dibayarkan atau outflows tersebut dapat dalam bentuk bunga, pokok pinjaman (principal) atau bentuk deviden (Najmudin 2011, 320-321). 333):

Yang mencakup biaya modal yaitu sebagai berikut (Najmudin 2011, 329-

1. Saham preferen. Saham preferen mempunyai karakteristik campuran antara hutang dan saham biasa. Saham preferen bersifat seperti huatang karena mengandung kewajiban yang tetap bagi perusahaan untuk melaksanakan pembayaran secara periodik yaitu deviden saham preferen seperti bunga. Dalam likuidasi perusahaan, pemegang saham preferen mempunyai hak didahulukan sebelum pemegang saham biasa. Namun tidak seperti hutang, kegagalan membayar deviden saham preferen tidak mengakibatkan pembubaran perusahaan. Biaya modal yang berasal dari penjualan saham preferen atau disingkat biaya saham preferen (cost of preferred stock) dapat dihitung dengan membagi deviden per lembar saham preferen dengan harga bersih yang diperoleh dari penjualan selembar saham preferen baru.

2. Laba ditahan. Sumber dana laba ditahan juga seperti sumber dana lainnya yang harus diperhitungkan biayanya. Seandainya sumber ini tanpa biaya, lebih baik laba tersebut dikembalikan kepada pemiliknya, yaitu pemilik modal sendiri. Dengan demikian mereka mempunyai kesempatan untuk 
menggunakan modal tersebut pada investasi lain sehingga dari investasi tersebut dapat diperoleh tambahan laba. Biaya modal laba ditahan diasumsikan sama dengan biaya modal saham biasa.

3. Saham baru. Biaya saham biasa yang baru diterbitkan (cost of new common stock) tentu lebih tinggi daripada biaya laba ditahan karena dalam penerbitan saham baru dibebani adanya biaya emisi (floatation cost).

Biaya modal ekuitas (cost of equity capital) perusahaan dihitung berdasarkan tingkat diskonto yang dipakai investor untuk menilaitunaikan future cash flow. Estimasi cost of equity capital menggunakan pendekatan Ohlson (1995) yaitu:

$\mathrm{r}=\left(\mathrm{Bt}+\mathrm{X}_{\mathrm{t}+1}-\mathrm{Pt}\right) / \mathrm{Pt}$

keterangan :

$\mathrm{r}$ = biaya modal ekuitas

$\mathrm{Bt}=$ nilai buku per lembar saham periode $\mathrm{t}$

$\mathrm{X}_{\mathrm{t}+1}=$ laba per lembar saham pada periode $\mathrm{t}+1$ yang diestimasi dengan model random walk seperti pada persamaan (2)

$\mathrm{Pt}=$ harga saham pada periode $\mathrm{t}$.

\section{Konsep Return On Assets (ROA)}

Return On Assets (ROA) atau yang sering disebut juga dengan Return On Investment (ROI) adalah merupakan pengukuran kemampuan perusahaan secara keseluruhan aktiva yang tersedia didalam perusahaan. Semakin tinggi ratio ini, semakin baik keadaan suatu perusahaan (Syamsuddin 2004, 63).

Secara matematis Return On Asset (ROA) dapat dirumuskan sebagai berikut:

$$
\text { ROA }=\frac{\text { Laba Bersih Setelah Pajak }}{\text { Total Aktiva }}
$$

\section{METODOLOGI PENELITIAN}

Penelitian ini menggunakan pendekataan kuantitatif. Metode penelitian kuantitatif dapat diartikan sebagai metode penelitian yang berlandaskan kepada filsafat positivisme, digunakan meneliti untuk populasi atau sampel tertentu, pengumpulan data menggunakan instrumen penelitian, analisis data bersifat kuantitatif statistik dengan tujuan untuk mnguji hipotesis yang telah ditetapkan (Sugiyono 2017, 8).

Sumber data yang digunakan dalam pebelitian ini yaitu data sekunder adalah data yang diperoleh secara tidak langsung untuk mendapatkan informasi (keterangan) dari objek yang diteliti, biasanya data tersebut diperoleh dari tangan kedua baik dari objek secara individual (responden) maupun dari suatu badan (instansi) yang dengan sengaja melakukan pengumpulan data dari instansi-instansi atau badan lainnya untuk keperluan penelitian dari para penggunanya (Supangat 2010, 2).

Dalam penelitian ini terdiri dari variabel bebas (independen) yaitu manajemen laba, variabel terikat (dependen) yaitu perencanaan biaya modal ekuitas dan variabel moderator yaitu Return On Assets (ROA). 


\section{HASIL DAN PEMBAHASAN}

\section{Pengukuran Reflektif, Formatif dan Struktural}

Berdasarkan pengukuran reflektif, formatif dan struktural dengan menggunakan program Smart PLS versi 3.0 dapat diperoleh hasil sebagai berikut:

1. Pengukuran refleksif, dalam pengukuran ini dilakukan pengujian sebagai berikut:

a. Construct Validity and Reliability

Gambar 2

Hasil Uji Construct Validity and Reliability

\begin{tabular}{|c|c|c|c|c|c|c|c|}
\hline \multicolumn{8}{|c|}{ Construct Reliability and Validity } \\
\hline \multirow[t]{2}{*}{ Matrix } & \multirow[t]{2}{*}{ 掉筆 Cronbach's Alpha } & 掉等 rho_A & \multicolumn{2}{|c|}{ 掉革 Composite Reliability } & \multicolumn{2}{|c|}{ 㨲革 Average Variance Extracted ... } & \multirow{2}{*}{$\begin{array}{l}\text { Copy to Clipboar } \\
\text { Extracted (AVE) }\end{array}$} \\
\hline & & Cronbach' & 's Alpha & rho_A & posite Reliability & Average Variance & \\
\hline \multicolumn{2}{|c|}{ Manajemen Laba_(X) } & & 1.000 & 1.000 & 1.000 & & 1.000 \\
\hline \multicolumn{2}{|c|}{ Perencanaan Biaya Modal Ekuitas_( $(Y)$} & & 1.000 & 1.000 & 1.000 & & 1.000 \\
\hline \multicolumn{2}{|l|}{ ROA_(Z) } & & 1.000 & 1.000 & 1.000 & & 1.000 \\
\hline \multicolumn{2}{|l|}{$x^{\star} Z$} & & 1.000 & 1.000 & 1.000 & & 1.000 \\
\hline
\end{tabular}

Berdasarkan output Gambar 2 hasil uji Construct Validity and Reliability diatas menunjukkan untuk manajemen laba $(X)$, perencaanaan biaya modal ekuitas (Y), ROA (Z) dan moderating hubungan antara manajemen laba terhadap perencanaan biaya modal ekuitas $\left(\mathrm{X}^{*} \mathrm{Z}\right)$ memiliki nilai Cronbach's Alpha sebesar $1.000>0,70$, maka dapat dijelaskan bahwa data dapat dikatakan reliabel. Untuk nilai Composite Reliability sebesar 1,000 > 0,60, maka dapat dijelaskan bahwa data dapat dikatakan konsisten dan nilai AVE 1,000 > 0,50, maka dapat dijelaskan bahwa data dapat dikatakan valid.

b. Validitas diskriminan atau Discriminant Validity

\section{Gambar 3}

\section{Hasil Discriminant Validity}

\begin{tabular}{|c|c|c|c|c|c|c|c|}
\hline \multicolumn{8}{|l|}{ Discriminant Validity } \\
\hline \multirow[t]{2}{*}{ Fornell-Larcker Criteri... } & \multicolumn{2}{|c|}{ 囯 Cross Loadings } & \multicolumn{2}{|c|}{ Heterotrait-Monotrait R... } & \multicolumn{2}{|c|}{ 㩰 Heterotrait-Monotrait R... } & \multirow{2}{*}{$\frac{\text { Copyt }}{X^{\star} Z}$} \\
\hline & & \multicolumn{2}{|c|}{ Manajemen Laba_(X) } & \multicolumn{2}{|c|}{ Perencanaan Biaya Modal Ekuitas_(Y) } & ROA_(Z) & \\
\hline \multicolumn{3}{|l|}{ Manajemen Laba_ $(X)$} & 1.000 & & & & \\
\hline \multicolumn{2}{|c|}{ Perencanaan Biaya Modal Ekuitas_( $(Y)$} & & 0.186 & & 1.000 & & \\
\hline \multicolumn{2}{|l|}{ ROA_(Z) } & & 0.124 & & -0.224 & 1.000 & \\
\hline \multicolumn{2}{|l|}{$X^{\star} Z$} & & 0.270 & & -0.012 & 0.059 & 1.000 \\
\hline
\end{tabular}

Berdasarkan output Gambar 3 hasil Discriminant Validity diatas menunjukkan untuk manajemen laba $(X)$, perencaanaan biaya modal ekuitas (Y), ROA (Z) dan moderating hubungan antara manajemen laba terhadap perencanaan biaya modal ekuitas $\left(\mathrm{X}^{*} \mathrm{Z}\right)$ memiliki nilai discriminant validity sebesar $1.000>$ korelasi antar konstruk yang lain 
maka dapat dijelaskan bahwa data dapat dikatakan memiliki nilai discriminant validity yang baik.

2. Pengukuran formatif, dalam pengukuran ini dilakukan pengujian Colliniearity Statistics (VIF) dan signifikansi nilai weight.
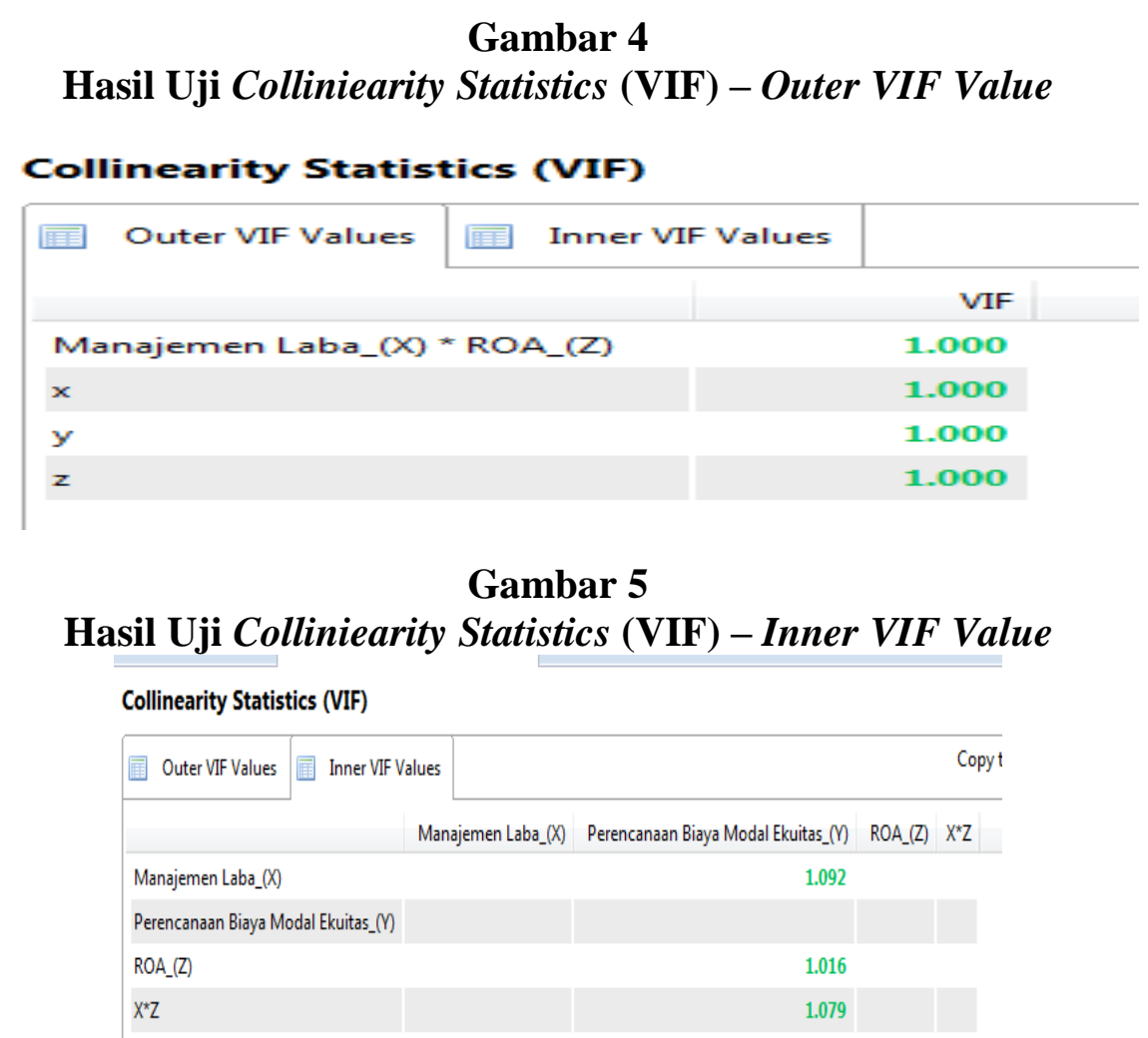

Berdasarkan output Gambar 4 hasil uji Colliniearity Statistics (VIF) - Outer VIF Value diatas menunjukkan untuk manajemen laba (X), perencaanaan biaya modal ekuitas (Y), ROA (Z) dan moderating hubungan antara manajemen laba terhadap perencanaan biaya modal ekuitas $\left(X^{*} \mathrm{Z}\right)$ memiliki nilai VIF sebesar $1.000<10$, maka dapat dijelaskan bahwa data dapat dikatakan bebas multikolinieritas untuk masing-masing variabel. Sedangkan pada output Gambar 5 hasil uji Colliniearity Statistics (VIF) - Inner VIF Value diatas menunjukkan bahwa untuk manajemen laba (X) terhadap perencaanaan biaya modal ekuitas (Y) memiliki nilai VIF sebesar 1,092 < 10, ROA (Z) terhadap perencaanaan biaya modal ekuitas (Y) memiliki nilai VIF sebesar $1,016<10$, moderating hubungan antara manajemen laba terhadap perencanaan biaya modal ekuitas $\left(\mathrm{X}^{*} \mathrm{Z}\right)$ terhadap perencaanaan biaya modal ekuitas (Y) memiliki nilai VIF sebesar $1,079<10$. Maka dapat dijelaskan pada Inner VIF Value bahwa masing-masing hubungan variabel dapat dikatakan bebas multikolinieritas. 


\section{Gambar 6 \\ Hasil Uji Signifikansi Nilai Weight}

\section{Path Coefficients}

\begin{tabular}{|c|c|c|c|c|c|c|}
\hline \multirow[t]{2}{*}{ Mean, STDEV, T-Values, P-Va... 目 Confidence Intervals } & \multicolumn{2}{|c|}{ 囯 Confidence Intervals Bias $\mathrm{C}_{\ldots . .}$} & 同 Samples & Copy & C Clipboard: & Excel Format \\
\hline & Original Sample (0) & Sample Mean & (... Standard [ & Devia... & TStatistics $(\mid 0$. & PValues \\
\hline Manajemen Laba_(X) -> Perencanaan Biaya Modal Ekuitas_( $($ ) & 0.233 & 0.2 & 30 & 0.102 & 2.293 & 0.022 \\
\hline ROA_(Z) -> Perencanaan Biaya Modal Ekuitas_(M) & -0.250 & -0.2 & 247 & 0.105 & 2,369 & 0.018 \\
\hline X`Z -> Perencanaan Biaya Modal Ekuitas_(M) & -0.058 & -0.0 & 072 & 0,106 & 0.553 & 0.581 \\
\hline
\end{tabular}

Gambar 7

\section{Output Hasil Bootstrapping}

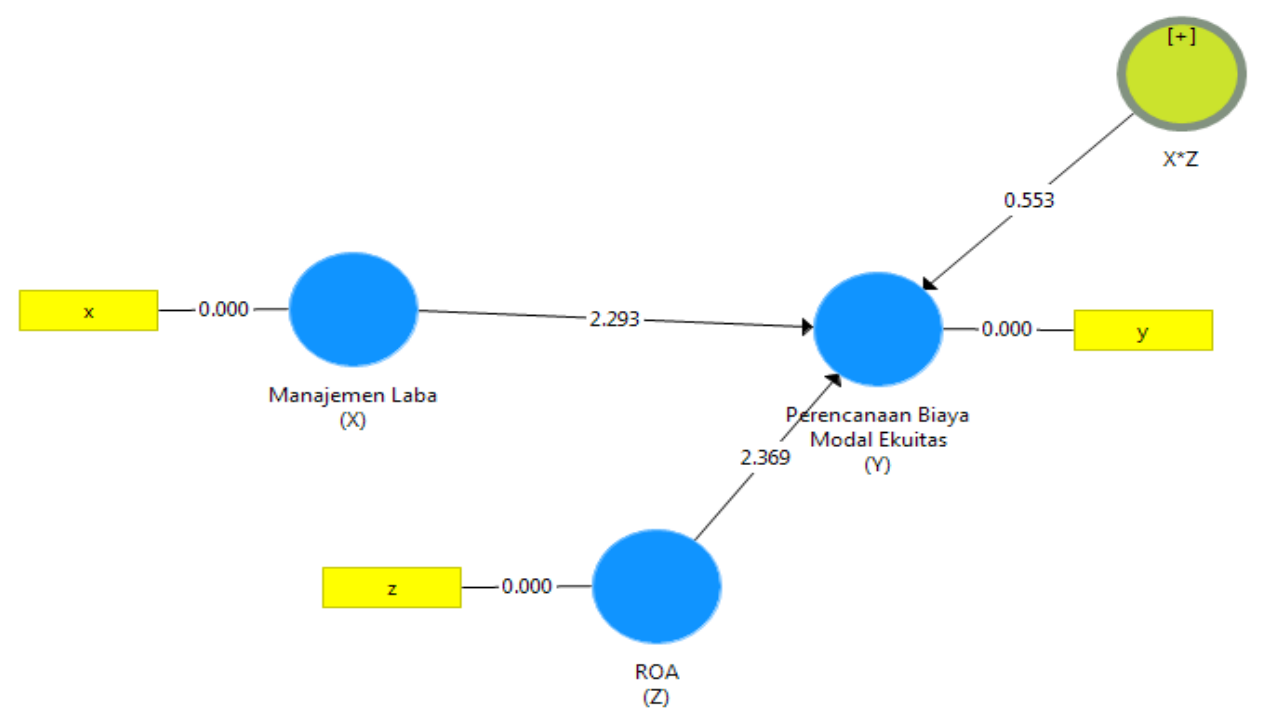

Berdasarkan output Gambar 6 hasil uji Signifikansi nilai weight dan Gambar 7 output hasil bootstrapping diatas menunjukkan bahwa:

a. Nilai $P$ Value manajemen laba $(\mathrm{X})$ terhadap perencaanaan biaya modal ekuitas (Y) sebesar 0,022 < 0,05 dan $T$ Statistics manajemen laba (X) terhadap perencaanaan biaya modal ekuitas (Y) sebesar 2,293>1,96 serta nilai original sampelnya sebesar 0,233 yang merupakan nilai koefisien dimana arah koefisien ini dapat dijelaskan bahwa jika variabel independen lain nilainya tetap dan manajemen laba $(\mathrm{X})$ mengalami kenaikan $1 \%$ maka perencanaan biaya modal ekuitas (Y) akan mengalami peningkatan sebesar 0,233. Dalam hal ini dapat dikatakan bahwa manajemen laba (X) berpengaruh positif terhadap perencaanaan biaya modal ekuitas $(\mathrm{Y})$.

b. Nilai $P$ Value ROA $(\mathrm{Z})$ terhadap perencaanaan biaya modal ekuitas (Y) sebesar $0,018<0,05$ dan $T$ Statistics manajemen laba $(\mathrm{X})$ terhadap perencaanaan biaya modal ekuitas $(\mathrm{Y})$ sebesar 2,369>1,96 serta nilai original sampelnya sebesar -0,250 yang merupakan nilai koefisien dimana arah koefisien ini dapat dijelaskan bahwa jika variabel independen lain nilainya tetap dan ROA (Z) mengalami kenaikan $1 \%$ maka perencanaan 
biaya modal ekuitas (Y) akan mengalami penurunan sebesar 0,250. Dalam hal ini dapat dikatakan bahwa ROA (Z) berpengaruh negatif terhadap perencaanaan biaya modal ekuitas $(\mathrm{Y})$.

c. Nilai $P$ Value $\mathrm{X} * \mathrm{Z}$ terhadap perencaanaan biaya modal ekuitas $(\mathrm{Y})$ sebesar 0,581 > 0,05 dan $T$ Statistics $\mathrm{X} * \mathrm{Z}$ terhadap perencaanaan biaya modal ekuitas (Y) sebesar 0,553 < 1,96 serta nilai original sampelnya sebesar 0,058 yang merupakan nilai koefisien dimana arah koefisien ini dapat dijelaskan bahwa jika variabel independen lain nilainya tetap dan moderasi $\left(\mathrm{X}^{*} \mathrm{Z}\right)$ mengalami kenaikan $1 \%$ maka perencanaan biaya modal ekuitas (Y) akan mengalami penurunan sebesar 0,058. Dalam hal ini maka dapat dikatakan bahwa $\mathrm{X} * \mathrm{Z}$ tidak mampu memoderasi hubungan antara manajemen laba terhadap perencanaan biaya modal ekuitas.

3. Pengukuran struktural

\section{Gambar 8}

\section{Hasil Uji $R$ Square Hubungan Antara Konstruk Manajemen Laba} Terhadap Perencanaan Biaya Modal Ekuitas

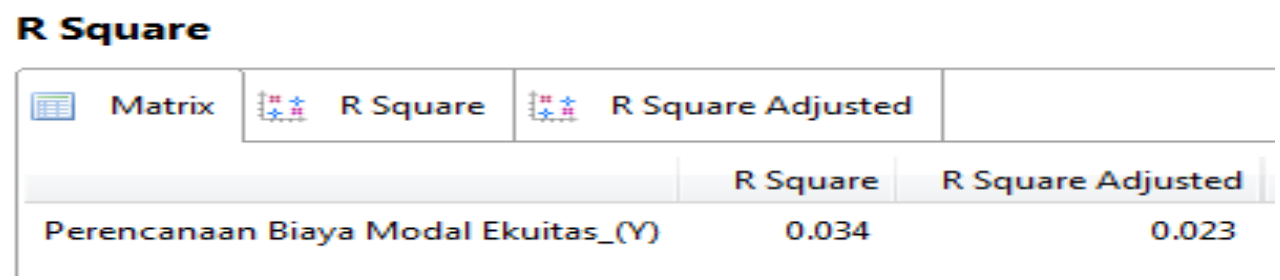

\section{Gambar 9 \\ Output Hasil PLS Algorithm Hubungan Antara Konstruk Manajemen Laba Terhadap Perencanaan Biaya Modal Ekuitas}

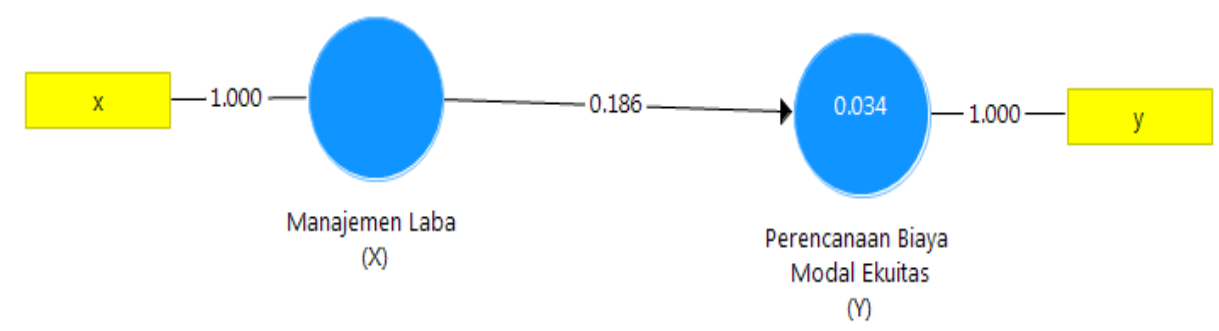

Berdasarkan output Gambar 8 dan Gambar 9 diatas menunjukkan bahwa nilai $R$ Square sebesar 0,034 berarti variabilitas konstruk perencaanaan biaya modal ekuitas (Y) yang dapat dijelaskan oleh konstruk manajemen laba (X) sebesar 3,4\%. Dalam hasil pengujian ini mengindikasi model lemah karena $R$ Square sebesar $0,034<0,19$. Sehingga dapat diartikan bahwa variabilitas konstruk perencaanaan biaya modal ekuitas (Y) yang dapat dijelaskan oleh konstruk manajemen laba (X) mempunyai hubungan yang lemah sebesar 0,034. Dengan pengaruh yang kecil bisa diartikan bahwa investor sudah mengantisipasi dengan benar informasi yang terkait dengan manajemen laba dengan beberapa teknik yang dilakukan seperti mengubah metode depresiasi, mengubah umur harta, mengubah nilai sisa harta, menetapkan cadangan piutang tak tertagih, menetapkan cadangan kewajiban jaminan garansi, menentukan adanya kerusakan harta, mengestimasi tahap penyelesaian 
kontrak dengan metode persentase penyelesaian, mempertimbangkan jumlah persediaan yang dihapus, dan tidak menutup periode akuntansi. Dalam hal ini dikarenakan pihak manajemen melakukan beberapa metode yaitu dengan menggunakan fleksibilitas yang diperbolehkan dalam akuntansi yang berlaku umum prinsip (GAAP) untuk mengubah laporan laba-rugi tanpa mengubah arus kas yang mendasari sebagai penggunaan penilaian manajerial dalam pelaporan keuangan dan mengubah keputusan operasi, seperti jadwal pengiriman atau perawatan, agar mengelola arus kas yang mendasari yang akan mempengaruhi laporan pendapatan yang dilaporkan sebagai penataan transaksi.

\section{Gambar 10}

\section{Hasil Uji $R$ Square Hubungan Antara Konstruk ROA Terhadap Perencanaan Biaya Modal Ekuitas}

\section{R Square}

\begin{tabular}{|c|c|c|c|c|c|c|}
\hline \multirow[t]{2}{*}{ 闻 } & \multirow[t]{2}{*}{ Matrix } & \multirow[t]{2}{*}{ 罣草 } & R Square & 䎨章 & R Square Adjusted & \\
\hline & & & & & R Square & R Square Adjusted \\
\hline $\mathrm{Pe}$ & encana: & $\mathrm{Bia}$ & ra Modal & uitas_(Y) & 0.050 & 0.040 \\
\hline
\end{tabular}

\section{Gambar 11}

Output Hasil PLS Algorithm Hubungan Antara Konstruk ROA Terhadap Perencanaan Biaya Modal Ekuitas

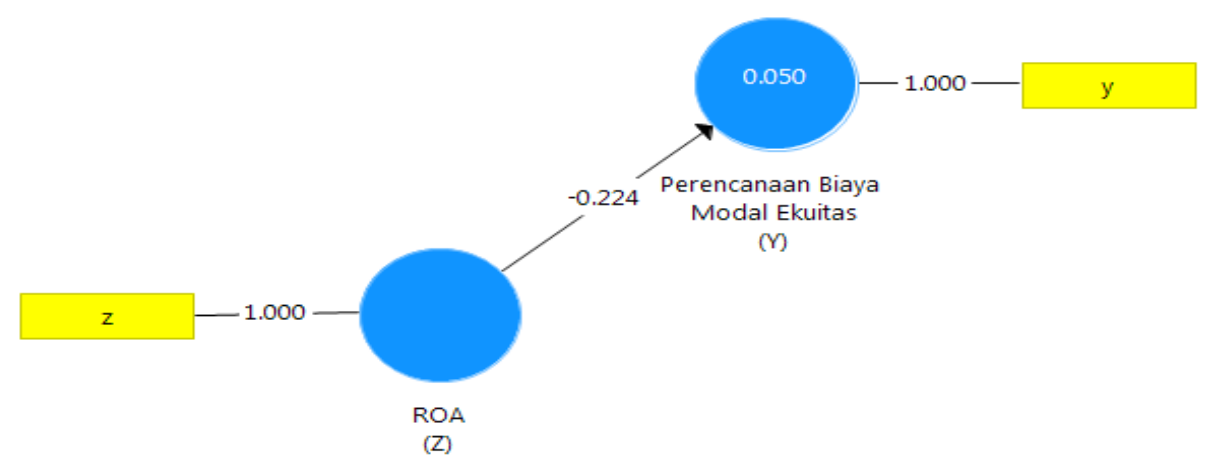

Berdasarkan output Gambar 10 dan Gambar 11 di atas menunjukkan bahwa nilai $R$ Square sebesar 0,050 berarti variabilitas konstruk perencaanaan biaya modal ekuitas (Y) yang dapat dijelaskan oleh konstruk ROA (Z) dan interaksinya sebesar 5\%. Dalam hasil pengujian ini mengindikasi model lemah karena $R$ Square sebesar $0,050<0,19$. Sehingga dapat diartikan bahwa variabilitas konstruk perencaanaan biaya modal ekuitas (Y) yang dapat dijelaskan oleh konstruk manajemen laba (X), ROA (Z) mempunyai hubungan yang lemah sebesar 0,050. Dengan pengaruh ini ROA merupakan salah satu rasio yang penting dalam suatu perusahaan untuk menggambarkan kondisi perusahaan yang juga akan dilihat oleh para investor. Besarnya ROA ini juga dipengaruhi oleh faktor tingkat perputaran aktiva yang digunakan untuk operasi dan memperbesar profit margin dengan tujuan untuk mempertinggi efisiensi disektor produksi, penjualan dan administrasi. 


\section{Gambar 12 \\ Hasil Uji $R$ Square Hubungan Antara Konstruk Manajemen Laba, ROA Dan Interaksinya}

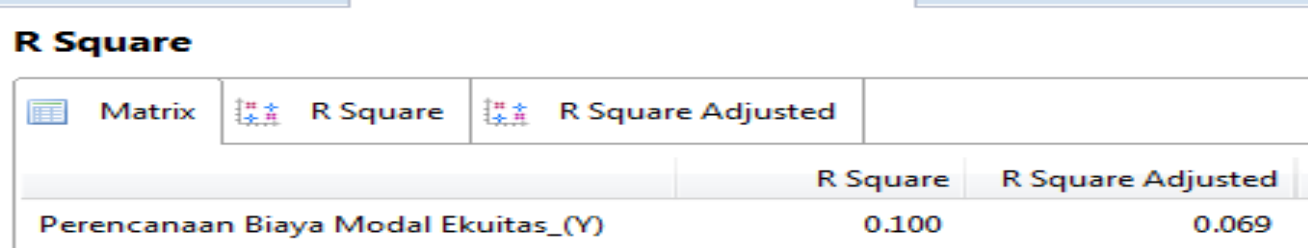

\section{Gambar 13}

Output Hasil PLS Algorithm Hubungan Antara Konstruk Manajemen Laba, ROA Dan Interaksinya

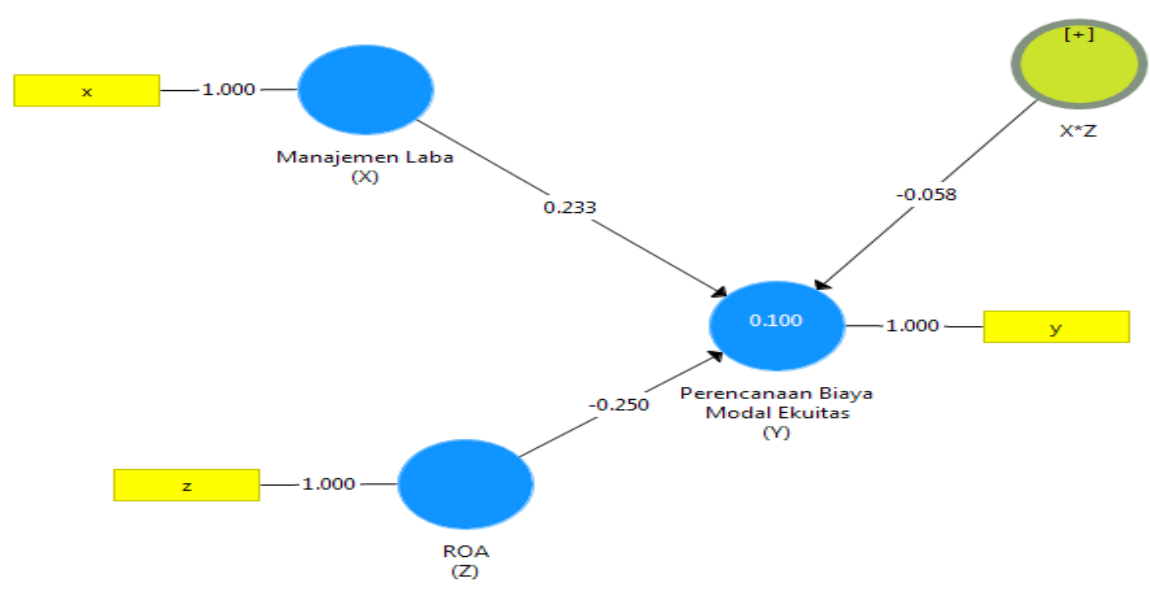

Berdasarkan output Gambar 12 dan Gambar 13 di atas menunjukkan bahwa nilai $R$ Square sebesar 0,100 berarti variabilitas konstruk perencaanaan biaya modal ekuitas (Y) yang dapat dijelaskan oleh konstruk manajemen laba (X), ROA (Z) dan interaksinya sebesar $10 \%$. Dalam hasil pengujian ini mengindikasi model lemah karena $R$ Square sebesar $0,100<0,19$. Sehingga dapat diartikan bahwa variabilitas konstruk perencaanaan biaya modal ekuitas (Y) yang dapat dijelaskan oleh konstruk manajemen laba (X), ROA (Z) mempunyai hubungan yang lemah sebesar 0,100 . Dalam hal ini hubungan dari dari gabungan veriabel manajemen laba dan ROA terhadap perencanaan biaya modal ekuitas lebih besar dibandingkan dengan hubungan antar variabel masing-masing, ini dapat dijelaskan bahwa investor tidak hanya menilai dari satu sisi saja dengan melihat dari laba yang dihasilkan tetapi rasio yang menggambarkan kondisi perusahaan yang sebenarnya pun juga menjadi pertimbangan bagi investor dalam menanamkan sahamnya kepada sebuah perusahaan go public terutama diperusahaan sektor industri makanan. 


\section{Gambar 14 \\ Hasil Uji F Square}

\begin{tabular}{|c|c|c|c|c|c|}
\hline \multicolumn{6}{|l|}{ f Square } \\
\hline \multirow[t]{2}{*}{ Matrix } & 抄萃 f Square & & & & Copy \\
\hline & & Manajemen Laba_ $(X)$ & Perencanaan Biaya Modal Ekuitas_( $(Y)$ & ROA_(Z) & $X^{\star} Z$ \\
\hline \multicolumn{3}{|c|}{ Manajemen Laba_ $(X)$} & 0.055 & & \\
\hline \multicolumn{6}{|c|}{ Perencanaan Biaya Modal Ekuitas_( $(N)$} \\
\hline \multicolumn{3}{|l|}{ ROA_(Z) } & 0.068 & & \\
\hline \multicolumn{2}{|l|}{$X^{\star} Z$} & & 0.004 & & \\
\hline
\end{tabular}

Berdasarkan output Gambar 14 hasil uji $f$ Square diatas menunjukkan bahwa nilai $f$ Square manajemen laba $(\mathrm{X})$ terhadap perencaanaan biaya modal ekuitas (Y) sebesar 0,055 > 0,02 maka manajemen laba (X) mempunyai pengaruh yang lemah terhadap perencaanaan biaya modal ekuitas (Y) dan ROA (Z) terhadap perencaanaan biaya modal ekuitas (Y) sebesar 0,068>0,02 maka ROA (Z) mempunyai pengaruh yang lemah terhadap perencaanaan biaya modal ekuitas (Y). Untuk nilai $f$ Square moderating hubungan antara manajemen laba terhadap perencanaan biaya modal ekuitas $\left(\mathrm{X}^{*} \mathrm{Z}\right)$ tidak mempunyai pengaruh terhadap perencaanaan biaya modal ekuitas (Y) karena nilai $f$ Square-nya sebesar $0,004<0,02$.

\section{Pengaruh Manajemen Laba Terhadap Perencanaan Biaya Modal Ekuitas}

Dari hasil penelitian yang telah dilakukan dalam pengujian hipotesis (h1), manajemen laba terhadap perencanaan biaya modal ekuitas memiliki nilai $P$ Value sebesar 0,022 < 0,05 dan T Statistik sebesar 2,293> 1,96 ini berarti ada pengaruh yang signifikan maka hasil dari hipotesis 1 dapat dinyatakan bahwa H0 ditolak dan Ha diterima artinya manajemen laba berpengaruh terhadap perencanaan biaya modal ekuitas. Pada Gambar IV. 5 hasil uji Signifikansi nilai weight dapat dilihat original sample manajemen laba terhadap perencanaan biaya modal ekuitas memiliki nilai sebesar 0,233 yang merupakan nilai koefisien dimana arah koefisien ini dapat dijelaskan bahwa jika variabel independen lain nilainya tetap dan manajemen laba $(\mathrm{X})$ mengalami kenaikan $1 \%$ maka perencanaan biaya modal ekuitas (Y) akan mengalami peningkatan sebesar 0,233 artinya manajemen laba berpengaruh positif terhadap perencanaan biaya modal ekuitas. Pengaruh yang yang terjadi pada manajemen laba terhadap perencanaan biaya modal ekuitas yaitu sebesar 3,4\% dan 96,6\% lagi dipengaruhi oleh faktor lain.

\section{Pengaruh Return On Assets (ROA) Memoderasi Pengaruh Manajemen Laba Terhadap Perencanaan Biaya Modal Ekuitas}

Dari hasil penelitian yang telah dilakukan dalam pengujian hipotesis (h2), Return On Assets (ROA) terhadap perencanaan biaya modal ekuitas memiliki nilai $P$ Value sebesar 0,018 < 0,05 dan T Statistik sebesar 2,369 > 1,96 ini berarti ada pengaruh yang signifikan. Pengaruh yang dihasilkan yaitu sebesar 5\%. Untuk moderating hubungan antara manajemen laba terhadap perencanaan biaya modal ekuitas memiliki nilai $P$ Value sebesar 0,581 > 0,05 dan $T$ Statistik sebesar 0,553 
$<1,96$ serta nilai original sampelnya sebesar $-0,058$ yang merupakan nilai koefisien dimana arah koefisien ini dapat dijelaskan bahwa jika variabel independen lain nilainya tetap dan moderasi $\left(\mathrm{X}^{*} \mathrm{Z}\right)$ mengalami kenaikan $1 \%$ maka perencanaan biaya modal ekuitas (Y) akan mengalami penurunan sebesar 0,058 berarti tidak ada pengaruh yang signifikan maka hasil dari hipotesis 2 dapat dinyatakan bahwa Ha ditolak dan H0 diterima artinya Return On Assets (ROA) tidak mampu memoderasi pengaruh manajemen laba terhadap perencanaan biaya modal ekuitas.

\section{PENUTUP}

Manajemen laba terhadap perencanaan biaya modal ekuitas diketahui bahwa manajemen laba (X) untuk nilai $P$ Value sebesar $0,022<0,05$ dan $T$ Statistics 2,293>1,96 serta nilai original sampelnya sebesar 0,233 yang merupakan nilai koefisien dimana arah koefisien ini dapat dijelaskan bahwa jika variabel independen lain nilainya tetap dan manajemen laba $(X)$ mengalami kenaikan $1 \%$ maka perencanaan biaya modal ekuitas (Y) akan mengalami peningkatan sebesar 0,233. Dalam hal ini dapat disimpulkan bahwa Ha diterima, artinya laba (X) berpengaruh terhadap perencaanaan biaya modal ekuitas (Y).

Return On Assets (ROA) terhadap perencaanaan biaya modal ekuitas untuk nilai $P$ Value sebesar $0,018<0,05$ dan $T$ Statistics 2,369 > 1,96. Tetapi untuk nilai $P$ Value moderating hubungan antara manajemen laba terhadap perencaanaan biaya modal ekuitas sebesar 0,581 > 0,05 dan T Statistics 0,553 < 1,96 maka dapat disimpulkan bahwa H0 diterima, artinya Return On Assets (ROA) tidak mampu untuk memoderasi hubungan antara manajemen laba terhadap perencanaan biaya modal ekuitas. Dalam hal ini Return On Assets (ROA) berubah kedudukan sebagai variabel penjelas/prediktor dimana suatu variabel dikatakan yang semula dihipotesiskan sebagai variabel moderasi, tetapi hasil pengujian menunjukkan bahwa variabel tersebut sebagai penjelas/prediktor.

\section{DAFTAR PUSTAKA}

Al-Aliy. 2013. Al Qur'an dan Terjemahan. Bandung: CV Penerbit Diponegoro. Anggraeni, Rina. 2019. "Strategi Pemerintah Tarik Investasi Manufaktur". https://ekbis.sindonews.com/read/1378453/34/ini-strategi-pemerintahtarik-investasi-manufaktur-1550062730. (diunduh pada hari selasa tanggal 01 januari 2019 pukul 19.30 wib).

Annual Report Profil Perusahaan.

Arikunto, Suharsimi. 2010. Metode Penelitian. Jakarta: PT Rineka Cipta.

Aziz, Royan. 2014. "Mari Intip Saham Sektor Konsumsi" https://www.seputarforex.com/analisa/mari-intip-saham-sektor-konsumsiyang-menarik-208100-21, (diunduh pada hari selasa tanggal 01 april 2019 pukul 19.30 wib).

Diantimala, Yossi. 2010. "Pengaruh Manajemen Laba Dan Reputasi Auditor". Jurnal Telaah \& Riset Akuntansi, Vol. 3, No. 2:126.

Fahmi, Irham. 2016. Pengantar Manajemen Keuangan. Bandung: Alfabeta.

Ghozali, Imam. 2014. Structural Equation Modeling Metode Alternatif Dengan Partial Least Square (PLS). Semarang: Badan Penerbit UNDIP. 
Hafidhuddin, Didin, dan Tanjung. 2003. Hendri. Manajemen Syariah Dalam Praktik. Jakarta: Gema Insani.

Hariwijaya, M.. 2008. Cara Mudah Menyusun Skripsi, Tesis dan Disertasi, Yogyakarta: Pararaton.

Hasibuan, Malayu S. P. 2014. Manajemen Dasar, Pengertian Dan Masalah. Jakarta: Bumi Aksara.

Ifonie, Regina Reizky. 2012. "Pengaruh Asimetri Informasi Dan Manajemen Laba Terhadap Cost Of Equity Capital Pada Perusahaan Real Estate Yang Terdaftar Di Bursa Efek Indonesia". Jurnal Ilmiah Mahasiswa Akuntansi, Vol. 1, No. 1:103-107.

Jumirin. 2011. "Pengaruh Manajemen Laba Terhadap Biaya Modal Ekuitas Pada Perusahaan Otomotif Yang Terdaftar Di Bursa Efek Indonesia". Jurnal Riset Akuntansi Dan Bisnis, Vol. 11, No. 2:195-198.

Karim, Adiwarman A. 2006. Bank Islam Analisis Fiqih dan Keuangan. Jakarta: PT. Raja Grafindo Persada.

Kurnia, Lisa, dan Arafat, M. Yasser. 2015. "Pengaruh Manajemen Laba Dan Ukuran Perusahaan Terhadap Biaya Modal Ekuitas Pada Perusahaan Manufaktur Yang Terdaftar Di Bursa Efek Indonesia”. Jurnal Ilmiah Wahana Akuntansi, Vol 10, No 1:52.

Manullang, M. 2005. Pengantar Manajemen Keuangan. Yogyakarta: Andi.

Munawir, S. 2004. Analisa Laporan Keuangan. Yogyakarta: Liberty.

Najmudin. 2011. Manajemen Keuangan dan Akuntansi Syar'iyyah Modern. Yogyakarta: Andi.

Noor, Juliansyah. 2012. Metode Penelitian. Jakarta: Kencana.

Purnomo, Budi S., dan Pratiwi, Puji. 2009. "Pengaruh Earning Power Terhadap Praktek Manajemen Laba (Earning Management)". Jurnal Media Ekonomi, Vol. 14, No 1.

Purwaningtias, Margareta Hastuti, dan Surifah. 2015. "Pengaruh Manajemen Laba Akrual Terhadap Biaya Modal Ekuitas Pada Perusahaan Manufaktur Yang Terdaftar Di Bursa Efek Indonesia (BEI) Tahun 2011-2013. Seminar Nasional Hasil-Hasil Penelitian Dan Pengabdian LPPM Universitas Muhammadiyah Purwokerto.

Rahmawati. 2012. Teori Akuntansi Keuangan. Yogyakarta: Graha Ilmu.

Riadi, Muchlisin. 2017. "Return on Assets (ROA)". https://www.kajianpustaka.com/2017/08/return-on-assets-roa.html

(diunduh pada hari minggu tanggal 06 januari 2019 pukul 19.30 wib)

Runturambi, Irene V., Winston Pontoh, dkk. 2017. "Analisis Manajemen Laba Pada Perusahaan Di Sektor Industri Food And Beverages Yang Terdaftar Di Bursa Efek Indonesia Tahun 2015-2016”. Jurnal Riset Akuntansi Going Concern, Vol. 12, No. 2:859-860.

Samryn, L. M. 2002. Akuntansi Manajerial Suatu Pengantar. Jakarta: PT Raja Grafindo Persada.

Siregar, Syofian. 2010. Statistika Deskripf Untuk Penelitian: Dilengkapi Perhitungan Manual dan Aplikasi SPSS Versi 17. Jakarta: PT Raja Grafindo Persada.

Siyoto, Sandu, dan Sodik, M. Ali. 2015. Dasar Metodologi Penellitian. Yogyakarta: Literasi Media Publishing. 
Solimun, Adji Achmad Rinaldo Fernandes, dkk. 2017. Metode Statistika Multivariate Pemodelan Persamaan Struktural (SEM) Pendekatan WarpPLS. Malang: UB Press.

Subramanyam, K. R., dan Wild, John J. 2011. Analisis Laporan Keuangan, Jakarta: Salemba Empat.

Sugiyono, 2012. Metode Penelitian Kombinasi. Bandung: Alfabeta.

Sugiyono, 2017. Metode Penelitian Kuantitatif, Kualitatif dan R\&D. Bandung: Alfabet.

Sulistyanto, Sri. 2014. Manajemen Laba Teori Dan Model Empiris. Jakarta: Grasindo.

Supangat, Andi. 2010. Statistika: Dalam Kajian Deskriptif, Inferensi Dan Nonparametrik. Jakarta: Kencana.

Sutrisno. 2001. Manajemen Keuangan Teori, Konsep Dan Aplikasi. Yogyakarta: Ekonisia.

Syamsuddin, Lukman. 2004. Manajemen Keuangan Perusahaan. Jakarta: PT Raja Grafindo.

Tisnawati, Ernie, dan Saefullah, Kurniawan. 2005 Pengantar Manajemen. Jakarta: Kencana.

Umar, Husein. 2005. Metode Penelitian Untuk Skripsi dan Tesis Bisnis. Jakarta: PT. Raja Grafindo Persada.

Watung, Rosdian Widiawati, dan Ilat, Ventje. 2016. "Pengaruh Return On Asset (ROA), Net Profit Margin (NPM), dan Earning Per Share (EPS) Terhadap Harga Saham Pada Perusahaan Perbankan Di Bursa Efek Indonesia Periode 2011-2015", Jurnal EMBA, Vol. 4, No. 2:518-529.

Yadiati, Winwin. 2007. Teori Akuntansi: Suatu Pengantar. Jakarta: Kencana.

Yusanto, Muhammad Ismail, dan Widjajakusuma, Muhammad Karebet. 2002. Menggagas Bisnis Islami. Jakarta: Gema Insani Press.

Fitriyani, "Pengaruh Manajemen Laba Terhadap Biaya Modal Ekuitas (Pada Perusahaan Manufaktur Yang Terdaftar Di Bursa Efek Indonesia)", Skripsi, Bandung: Program Sarjana Universitas Widyatama, 2015.

https://www.maxmanroe.com/vid/manajemen/pengertian-perencanaan.html (diunduh pada hari rabu tanggal 02 januari 2019 pukul 20.00 wib) 